\title{
NO-LINEAR RESPIRATION DYNAMICS IN A DEGRADED ALFISOL AMENDED WITH DIFFERENT DOSE OF SALMON SLUDGES
}

\author{
J.E. Celis ${ }^{1 *}$, M.A. Sandoval ${ }^{2}$ and N. Bello ${ }^{2}$ \\ ${ }^{1}$ Departamento de Ciencias Pecuarias, Facultad de Ciencias Veterinarias, Universidad de \\ Concepción, Av. Vicente Méndez 595, Chillán, Chile. \\ ${ }^{2}$ Departamento de Suelos y Recursos Naturales, Facultad de Agronomía, Universidad de \\ Concepción, Av. Vicente Méndez 595, Chillán, Chile. \\ *Corresponding author: jcelis@udec.cl
}

\begin{abstract}
No research has been conducted regarding respiration model parameters as a consequence of the application of salmon sludge on degraded Alfisols. In order to investigate kinetic parameters representing the decomposition of salmon sludge by means of respiration rates, sediment samples from a land-farmed pisciculture and a lake-salmon facility were applied to a degraded Alfisol at the Biobío region (Chile). Soil microbiological activity was evaluated on a 60-days laboratory incubation experiment under different salmon sludge addition dose: $\mathrm{T}_{1}: 25 \mathrm{t} \mathrm{ha}^{-1} ; \mathrm{T}_{2}: 50 \mathrm{t} \mathrm{ha}^{-1} ; \mathrm{T}_{3}$ : $75 \mathrm{t} \mathrm{ha}^{-1} ; \mathrm{T}_{4}: 100 \mathrm{t} \mathrm{ha}^{-1} ; \mathrm{T}_{5}: 150 \mathrm{t} \mathrm{ha}^{-1}$. A non-amended soil served as control. $\mathrm{CO}_{2}-\mathrm{C}$ production was determined in samples under closed incubation. A two-component firstorder regression model was applied to $\mathrm{CO}_{2}-\mathrm{C}$ curves to obtain kinetic parameter values of $\mathrm{C}$ mineralization. The analysis confirmed that microorganisms increased their respiratory activity with time and increased sludge concentration $(p \leq 0.05)$. A higher microbial activity was noted when soil was amended with land-farmed sludge at 100 and $150 \mathrm{t} \mathrm{ha}^{-1}$, particularly after 30 days of incubation. The model showed that microorganisms needed more time to decompose labile $\mathrm{C}$ compounds in the salmon sludge when dose increased above $100 \mathrm{t} \mathrm{ha}^{-1}$. After 60 days of incubation, land-farmed sludge amended at $25 \mathrm{t} \mathrm{ha}^{-1}$ accumulated $44 \%$ of $\mathrm{CO}_{2}-\mathrm{C}$ from a labile $\mathrm{C}$ source and $56 \%$ from a mineralized $\mathrm{C}$ pool, whereas at $150 \mathrm{t} \mathrm{ha}^{-1}$ showed a $76 \%$ of a labile $\mathrm{C}$ and $24 \%$ mineralized C.
\end{abstract}

Keywords: Aquaculture, decomposition of organic matter, k-value, biosolids, soil remediation, biological activity.

\section{INTRODUCTION}

The explosive demand for fish in the world has implied Chile increased salmon production, rising from 50,000 annual tons in 1990 to near 400,000 tons in 2007, placing it among the main producer of salmon-farmed around the world (Salazar et al., 2005).
In spite of the temporal brake that affected Chilean's salmon exports in last months, this remarkable development also has generated important volumes of organic residues from intensive salmonfarming facilities, representing a problem of contamination for aquatic ecosystems 
(Teuber et al., 2007). Solid wastes correspond mainly of no consumed food and fecal material that accumulates on pool's bottom (in the case of a landfarming salmon pisciculture) or on lake's bottom (case of a lake-salmon farming facility).

Organic materials addition to soil stimulates microbial population so improving the fertility and properties of some Chilean volcanic soils (Millaleo et al., 2006). Also, it has been found that the application of salmon wastes increased microbiological activity in degraded Patagonian soils (Celis et al., 2009). On the other hand, there is an enormous potential for recycling organic residues in Alfisols of the Coastal Mountains at the Biobío region (Chile), even though there is a lack of appropriate studies on the subject. These soils are located in the Chilean Sub-Humid Interior Dryland of the Coastal Mountains, which constitutes one of the regions more affected by erosion, amounting around 2 million hectares between the latitudes $32^{\circ} 00^{\prime} \mathrm{S}$ and $37^{\circ} 00^{\prime} \mathrm{S}$ (Pérez and González, 2001). These soils were highly impacted in the past 100 years to satisfy cereal demand production, actually having very low $\mathrm{OM}$ content in the profile, and usually no A horizon. Chilean Sub-Humid Interior Dryland of the Coastal Montains is an enormous area considered marginal and poor, which has been severely affected by anthropogenic activities that have practically exhausted almost all its natural resources (Muñoz et al., 2004). In this area, a rural population of approximately 350,000 people lives in very hard living conditions (Santibáñez and García, 2000). A study performed on these soils concluded that degradation due to erosion decreased microbial biomass as directly vegetal cover decreased (Muñoz et al., 2004). This implies a great potential for recovering these degraded soils as being used for recycling salmon sludges.
For biosolids can be successful applied in soils as organic amendments, a high degree of OM decomposition is needed to reach their biological stabilization, task that is carried out by a variety of microorganisms, as microfauna such as protozoa, bacteria, fungi, actinomycetes and yeasts (Pinochet et al., 2001). Biological stabilization implies an inhibition of the nitrification process. Nitrate, resultants of nitrification, is a very important polluting agent for underground and superficial water (Sawyer et al., 2000). For this reason, its reduction by microbial activity is an indicator of sludge stabilization. Sludge addition to soil increases microbial biomass because it incorporates a new microbial load to soil and also stimulates growth of the native microbiota due to a fresh C source (Ros et al., 2006). On the other hand, other studies reveal a decrease on microbial population for disturbing natural soil communities as a result of sludge addition (Jonsen et al., 2001, Crecchio et al., 2004).

The most important biological activities are those related to the $\mathrm{OM}$ and nutrient cycling (Alvear et al., 2007). Respiration is one of more frequently parameters used to quantify microbial activity in soil (Zagal et al., 2002). It is directly related to decomposition of organic residues of different types and sources (Sylvia et al., 1998). Metabolic activity performed by microorganisms in the decomposition process, can be determined by means of $\mathrm{CO}_{2}$ production or by the $\mathrm{O}_{2}$ consumed by microorganisms (Alef, 1995).

Chilean environmental regulations are recently being focused on protecting soils, where one of the parameters that need to be very well controlled is quantity of the sludge applied to soils. For that reason, it is extremely important to know the OM decomposition kinetic, thus adding information for designing better 
management practices mentioned by these environmental regulations. Unfortunately, there is a lack of research on the application of models in order to determine the values of the kinetic constants participating in $\mathrm{C}$ mineralization, a useful tool for estimating $\mathrm{OM}$ decomposition. In studying decomposition of organic materials, regression models have been used by several authors (Jenkinson, 1977; Janssen, 1984; Cheshire et al., 1988; Saviozzi et al., 1993). The twocomponent first-order regression model proposed by Jenkinson (1977) has been used successfully to describe the decomposition of plant residues (Marstorp and Kirchmann, 1991), and it is also expected to be useful to describe decomposition of salmon sludge. Consequently, the aims of this study were: 1) to determine microbial $\mathrm{CO}_{2}-\mathrm{C}$ evolution in a degraded Alfisol of the Biobío region amended with different amounts of salmon sludges; 2) to obtain no-linear coefficients from respiration curves to be correlated with OM decomposition.

\section{MATERIALS AND METHODS}

\section{In situ activities}

Sludge samples were obtained from two production systems of a salmon-farming industry located at southern Chile: (i) sediments extracted from pools of a landfarmed salmon pisciculture (land-farmed salmon sludge) and, (ii) sediments taken at a depth of $20 \mathrm{~m}$ beneath lake-salmon cages by using dredge (lake-farmed salmon sludge). The samples of the Alfisol were obtained at a depth of $20 \mathrm{~cm}$, coming from a sector of the Coastal Mountains of the Biobío region (Chile), near to the city of Quillón $\left(36^{\circ} 40^{\prime} \mathrm{S}\right.$ and $\left.72^{\circ} 27^{\prime} \mathrm{O}\right)$. Taxonomic classification of the soil studied corresponded to an Ultic Palexeralfs, a granitic soil highly physical-chemical and biological degraded, clayed texture, Cauquenes series, with slopes higher than 15\% (Stolpe et al., 2008). Sampling area belonged to Sub-Humid Interior Dryland of the Coastal Mountains, located in the eastern slope of the mountains, having a typically arborescent coastal scrub vegetation. Climate is Mediterranean with a prolonged dry station (six months), followed by a humid period with annual precipitation averaging $1,100 \mathrm{~mm}$ (Celis et al., 2007).

\section{In vitro activities}

Physical and chemical characterization of samples (soil and sludge) was determined at laboratories of the Department of Soil and Natural Resources of the University of Conception (certified by the Chilean Soil Science Society, since 2000). Table 1 shows some physical and chemical properties of soil and salmon sludge.

Sludge and soil samples were maintained to temperatures below $10^{\circ} \mathrm{C}$ before their processing in laboratory. After that, samples were dried to room temperature (15\% humidity, dry weight basis) and sieved (2 $\mathrm{mm}$ mesh). Immediately, different mixtures of sludge/soil based on $1 \mathrm{~kg}$ of soil each were prepared. Treatments consisted of different doses of sludge added to soil: $\mathrm{T}_{1}$ $=25 \mathrm{t} \mathrm{ha}^{-1} ; \mathrm{T}_{2}=50 \mathrm{t} \mathrm{ha}^{-1} ; \mathrm{T}_{3}=75 \mathrm{t} \mathrm{ha}^{-1}$; $\mathrm{T}_{4}=100 \mathrm{t} \mathrm{ha}^{-1} ; \mathrm{T}_{5}=150 \mathrm{t} \mathrm{ha}^{-1}$. A control (no sludge added to soil) was considered. The amended soil samples were homogenized, packaged in plastic bags, and then placed in a chamber (with temperature and humidity automatically controlled at $25^{\circ} \mathrm{C}$ and $60-70 \%$, respectively) for a 10 -days pre-incubation period. 
Table 1. Soil and salmon sludge characteristics $(n=3, \pm$ s.e.m).

\begin{tabular}{lccc}
\hline Parameter & Alfisol & Salmon & sludge \\
\cline { 3 - 4 } & & Land-farmed & Lake-farmed \\
\hline $\mathrm{Da}\left(\mathrm{g} \mathrm{cm}^{-3}\right)$ & $1.4 \pm 0.2$ & $0.9 \pm 0.1$ & $0.8 \pm 0.4$ \\
$\mathrm{pH}(\mathrm{al} \mathrm{agua})$ & $5.6 \pm 0.5$ & $7.0 \pm 0.6$ & $6.7 \pm 0.3$ \\
$\mathrm{OM}(\%)$ & $2.5 \pm 0.2$ & $20.7 \pm 1.3$ & $18.3 \pm 1.5$ \\
$\mathrm{~N}\left(\mathrm{mg} \mathrm{kg}^{-1}\right)$ & $9.8 \pm 0.8$ & $1,695.3 \pm 10.4$ & $746.0 \pm 11.3$ \\
$\mathrm{P}\left(\mathrm{mg} \mathrm{kg}^{-1}\right)$ & $5.4 \pm 0.9$ & $480.0 \pm 9.7$ & $19.9 \pm 3.2$ \\
$\mathrm{~K}\left(\mathrm{mg} \mathrm{kg}^{-1}\right)$ & $129.8 \pm 2.7$ & $30.0 \pm 8.9$ & $120.8 \pm 9.5$ \\
$\left.\mathrm{CIC}\left(\mathrm{cmol}^{-1}\right) \mathrm{kg}^{-1}\right)$ & $5.5 \pm 1.1$ & $1.7 \pm 0.7$ & $19.3 \pm 1.3$ \\
$\mathrm{C} / \mathrm{N}$ & $9.3 \pm 0.6$ & $10.5 \pm 1.3$ & $7.5 \pm 1.1$ \\
\hline
\end{tabular}

All the prepared mixtures were used for determining soil respiration, following the procedure described in literature (Zagal et al., 2002; Celis et al.; 2009). For the incubation process, samples consisting on $25 \mathrm{~g}$ of sludge/soil mixture were placed in glass bottles of $1 \mathrm{~L}$ capacity. Then, a test tube with $15 \mathrm{~mL}$ of solution $0.1 \mathrm{M} \mathrm{NaOH}$ (to absorb $\mathrm{CO}_{2}$ produced by microorganisms), and a tube with deionized water (to keep humidity constant) were placed in each jar. Following, each bottle was sealed hermetically with parafilm. A total of 44 bottles were set up for the experiment, considering the treatments (5), the control, the type of sludge (2) and replicates (4). Following, bottles were placed in an incubation chamber at $22^{\circ} \mathrm{C}$ by 60 days. Measurements of no neutralized $\mathrm{NaOH}$ along time were accomplished by titration $(0.1 \mathrm{M} \mathrm{HCl})$. Then, $1 \mathrm{~mL} \mathrm{NaOH}$ was extracted (in duplicate), and $2 \mathrm{~mL} \mathrm{BaCl}_{2}$ was added to precipitate the inorganic $\mathrm{C}$ as insoluble $\mathrm{BaCO}_{3}$. Drops of phenolphthalein were added as an acid base indicator, so no neutralized $\mathrm{NaOH}$ was titrated directly with $\mathrm{HCl}$ (Ianotti et al., 1994). The amount of $\mathrm{CO}_{2}-\mathrm{C}$ generated from the incubated mixtures was calculated by means of the formula proposed by Anderson (1982).

To obtain no-linear kinetic coefficients, the accumulated amounts of $\mathrm{CO}_{2}-\mathrm{C}$ measured during the incubation were fitted to a two-component first-order model, following the mathematical equation suggested by Jenkinson (1977):

$$
\text { (1) } Y=C_{1} \cdot\left(1-e^{-k_{1} \cdot t}\right)+C_{2} \cdot\left(1-e^{-k_{2} \cdot t}\right)
$$

where $\mathrm{Y}$ is the microbial respiration $(\mu \mathrm{g}$ $\mathrm{CO}_{2}-\mathrm{C} \mathrm{g}^{-1}$ soil), $\mathrm{C}_{1}$ and $\mathrm{C}_{2}$ are different pools of carbon subject to mineralization ( $\mu \mathrm{g} \mathrm{CO}_{2}-\mathrm{C} \mathrm{g}^{-1}$ soil), $\mathrm{k}_{1}$ and $\mathrm{k}_{2}$ are rate constants for the mineralization process $\left(d^{-1}\right)$, and $t$ is the time involved in the process (d).

\section{Statistical techniques}

Results obtained from in vitro respirometry trials were expressed as $\mu \mathrm{g}$ $\mathrm{CO}_{2}-\mathrm{C} \mathrm{g}^{-1}$ soil dry matter basis, oven at $105^{\circ} \mathrm{C}(24 \mathrm{~h})$. Cumulative curves on $\mathrm{CO}_{2}-$ $\mathrm{C}$ evolution were subjected to non-linear regression analyses using the NLIN procedure of SAS (SAS Institute Inc, Cary, NC, USA). Mean values for each 
sampling time were used. Data were processed by means of variance analysis ANOVA, and comparison among means was performed according to Turkey's test. In all cases the level of significance used was $95 \%(p \leq 0.05)$. The values were processed by means of statistical software SAS version 8.1 for Windows (SAS Institute Inc, Cary, NC, USA).

\section{RESULTS AND DISCUSSION}

Figure 1 shows the $\mathrm{C}-\mathrm{CO}_{2}$ evolution in the Alfisol amended with different doses of land-farmed sludge. In Figure 2 is shown microbial respiration in soil amended with lake-farmed salmon sludge.

When comparing both figures, it was noted amendments at 100 and $150 \mathrm{t} \mathrm{ha}^{-1}$ ( $\mathrm{T}_{4}$ and $\mathrm{T}_{5}$, respectively) notoriously produced more $\mathrm{CO}_{2}-\mathrm{C}$ than other treatments $(p \leq 0.05)$. It was particularly certain for land-farmed wastes after 30 days incubation. Similarly, lake-farmed sludge accumulated a significantly higher $\mathrm{CO}_{2}-\mathrm{C}$, but only 15 days incubation. In both cases a non-linear increasing trend on microbial activity along time was observed, similar to other studies carried out in amended Andisols using other organic residues (Zagal et al., 2002; Guerrero et al., 2007). It stated that amendments with salmon sludge clearly stimulated microorganism population when adding a new source of $\mathrm{C}$ to soil, in agreement with Ros et al. (2006).

In general, there was a higher microbial activity as the dose of sludge amended to the soil also increased, all the treatments being higher than the control. In the case of amendments with landfarmed sludge after 20 days incubation, amended treatments accumulated between 2 to 30 more $\mathrm{CO}_{2}-\mathrm{C}$ than control. It seems that higher $\mathrm{CO}_{2}-\mathrm{C}$ values had a greater $\mathrm{C}$ and energy availability for soil heterotrophic microorganisms, as a consequence of an abundant provision of $\mathrm{OM}$ and $\mathrm{N}$, so stimulating microbial activity (Zagal et al., 2002). For that reason and following the same pattern, treatments with lake-farmed sludge showed lower $\mathrm{CO}_{2}-\mathrm{C}$ values than landfarmed sludge amendments (sludge with higher $\mathrm{N}$ and $\mathrm{P}$ content, as shown in Table 1).

Evolution of $\mathrm{CO}_{2}-\mathrm{C}$ due to sludge addition to the Alfisol suggest a positive effect on microbial activity, as similarly has been reported by some studies in other soils (Zagal et al., 2002; Ros et al., 2003; Varnero et al., 2004; Teuber et al., 2007). According to Esparza et al. (2004) soils with low OM content, as the Alfisol here investigated $(2.5 \% \mathrm{OM})$, respond well to sludge addition. Similar results have been found in degraded Patagonian soils amended with salmon sludge (Celis et al., 2009). It can be explained because the addition of organic wastes stimulates microbial growth so increasing OM decomposition (Barrena et al., 2006).

Applying the two-component firstorder model to the result of the respirometry experiment clearly fitted the non-linear form as also found by Marstorp and Kirchmann (1991). The twocomponent first-order model represents the data in Figures 1 and 2. These expressions lines are used in the discussion to define two sludge decomposition rates: a pool of labile C, and a pool of mineralized C. In Table 2 are shown estimated kinetic parameters, i.e. the rate constants and pool sizes as a result of the non-linear regression fitted to cumulative curves on $\mathrm{CO}_{2}-\mathrm{C}$ evolution. Model seemed to be an acceptable twocomponent of $\mathrm{C}$ mineralization from sludge amendments in the Alfisol, based on high adjusted $r^{2}$ values. Carbon mineralization dynamics showed a decomposability of labile $\mathrm{C}$ compounds in the sludge material and a stabilized $\mathrm{C}$ not 


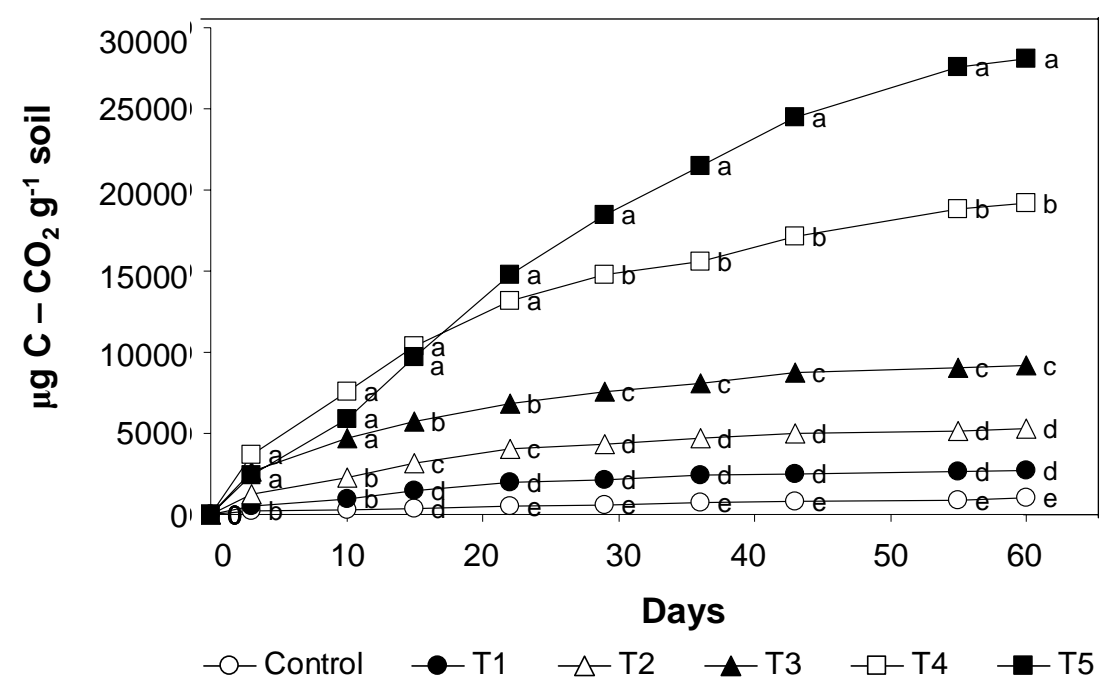

Figure 1. Accumulated C- $\mathrm{CO}_{2}$ evolution during laboratory incubation of an Alfisol under different amendments with land-farmed salmon sludge $\left(\mathrm{T}_{1}\right.$ : soil amended at $25 \mathrm{tha}^{-1} ; \mathrm{T}_{2}$ : soil amended at $50 \mathrm{t} \mathrm{ha}^{-1} ; \mathrm{T}_{3}$ : soil amended at $75 \mathrm{t} \mathrm{ha}^{-1} ; \mathrm{T}_{4}$ : soil amended at $100 \mathrm{t} \mathrm{ha}^{-1} ; \mathrm{T}_{5}$ : soil amended at $150 \mathrm{t} \mathrm{ha}^{-1}$ ). Different letters at the same time are significantly different $(p \leq$ $0.05)$.

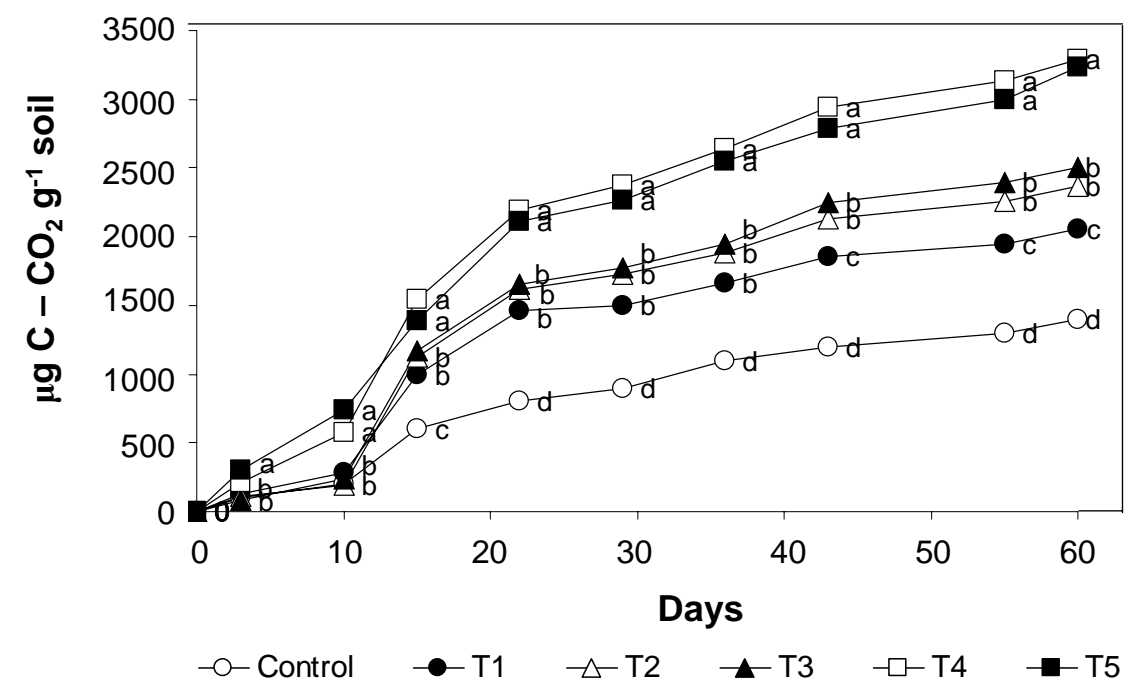

Figure 2. Accumulated $\mathrm{C}-\mathrm{CO}_{2}$ evolution during laboratory incubation of an Alfisol under different amendments with lake-farmed salmon sludge $\left(\mathrm{T}_{1}\right.$ : soil amended at $25 \mathrm{tha}^{-1} ; \mathrm{T}_{2}$ : soil amended at $50 \mathrm{t} \mathrm{ha}^{-1} ; \mathrm{T}_{3}$ : soil amended at $75 \mathrm{t} \mathrm{ha}^{-1} ; \mathrm{T}_{4}$ : soil amended at $100 \mathrm{t} \mathrm{ha}^{-1} ; \mathrm{T}_{5}$ : soil amended at $\left.150 \mathrm{t} \mathrm{ha}^{-1}\right)$. Different letters at the same time are significantly different $(p \leq$ $0.05)$. 
subject to mineralization during the period measured.

In the assessment, OM decomposition is considered to proceed in two steps: (1) decomposition of a labile $\mathrm{C}$; followed by (2) decomposition of a mineralized C. The model used by Jenkinson (1977) assumes that the sludge can be approximated to two different pools of constant but different decomposability. The first term of the equation $\left(C_{1} \cdot\left(1-e^{-k_{1} \cdot t}\right)\right)$ represents a pool of labile $\mathrm{C}$ and the second term $\left(C_{2} \cdot\left(1-e^{-k_{12} \cdot t}\right)\right)$ a pool of mineralized
C. Thus, at the end of incubation, landfarmed sludge applied to soil at a rate of $25 \mathrm{t} \mathrm{ha}^{-1}\left(\mathrm{~T}_{2}\right)$, produced an accumulated respiration of $2,947.9 \mu \mathrm{g}$ $\mathrm{CO}_{2}-\mathrm{C} \mathrm{g}^{-1}$ of soil. At this time, the proportion of labile $\mathrm{C}$ available for mineralization was about $44 \%$, whereas the proportion of mineralized $\mathrm{C}$ was $56 \%$. At the highest dose $\left(\mathrm{T}_{5}\right)$, an accumulated respiration of 29,611.1 $\mu \mathrm{g} \mathrm{CO}_{2}-\mathrm{C} \mathrm{g}^{-1}$ of soil was produced by microbial respiration, which was 10 times greater than $\mathrm{T}_{2}$. The labile $\mathrm{C}$ was $76 \%$ as opposed to a mineralized $\mathrm{C}$ of $24 \%$.

Table 2. Values of the constants for the equation $\left(Y=C_{1} \cdot e^{-k_{1} \cdot t}+C_{2} \cdot e^{-k_{2} \cdot t}\right)$ describing $\mathrm{C}-\mathrm{CO}_{2}$ production from microorganisms in an Alfisol amended with different doses of salmon sludges $\left(\mathrm{T}_{1}\right.$ : soil amended at $25 \mathrm{t} \mathrm{ha}^{-1} ; \mathrm{T}_{2}$ : soil amended at $50 \mathrm{t} \mathrm{ha}^{-1} ; \mathrm{T}_{3}$ : soil amended at $75 \mathrm{t} \mathrm{ha}^{-1} ; \mathrm{T}_{4}$ : soil amended at $100 \mathrm{t} \mathrm{ha}^{-1} ; \mathrm{T}_{5}$ : soil amended at $150 \mathrm{tha}^{-1}$ ).

\begin{tabular}{|c|c|c|c|c|c|}
\hline \multirow{2}{*}{ Treatments } & $\mathbf{k}_{1}$ & $\mathbf{k}_{2}$ & $\mathbf{C}_{1}$ & $\mathrm{C}_{2}$ & \multirow{2}{*}{$\mathbf{r}^{2}$} \\
\hline & \multicolumn{2}{|c|}{$\left(d^{-1}\right)$} & \multicolumn{2}{|c|}{$\left(\mu \mathrm{g} \mathrm{C}-\mathrm{CO}_{2} \mathrm{~g}^{-1}\right.$ soil) } & \\
\hline \multicolumn{6}{|c|}{ i) Land-farmed sludge } \\
\hline Control & 0.030 & 0.029 & 240 & 940 & 0.90 \\
\hline $\mathrm{T}_{1}$ & 0.037 & 0.031 & 1,460 & 1,950 & 0.91 \\
\hline $\mathrm{T}_{2}$ & 0.039 & 0.023 & 4,750 & 2,150 & 0.92 \\
\hline $\mathrm{T}_{3}$ & 0.049 & 0.033 & 7,110 & 4,160 & 0.90 \\
\hline $\mathrm{T}_{4}$ & 0.037 & 0.025 & 17,150 & 7,130 & 0.91 \\
\hline $\mathrm{T}_{5}$ & 0.027 & 0.021 & 27,870 & 10,130 & 0.90 \\
\hline \multicolumn{6}{|c|}{ ii) Lake-farmed sludge } \\
\hline Control & 0.031 & 0.029 & 1,170 & 470 & 0.89 \\
\hline $\mathrm{T}_{1}$ & 0.035 & 0.026 & 1,430 & 970 & 0.91 \\
\hline$T_{2}$ & 0.034 & 0.025 & 1,640 & 1,090 & 0.92 \\
\hline $\mathrm{T}_{3}$ & 0.036 & 0.027 & 1,870 & 980 & 0.90 \\
\hline $\mathrm{T}_{4}$ & 0.031 & 0.024 & 2,870 & 1,080 & 0.92 \\
\hline $\mathrm{T}_{5}$ & 0.029 & 0.025 & 2,860 & 1,040 & 0.93 \\
\hline
\end{tabular}


Comparatively, lake-farmed sludge amended at the lowest dose $\left(\mathrm{T}_{2}\right)$ showed an accumulated respiration from a labile $\mathrm{C}$ source of $1,426.7 \mu \mathrm{g} \mathrm{CO}_{2}-\mathrm{C} \mathrm{g}^{-1}$ of soil $(63 \%)$, and a respiration from a pool of $\mathrm{C}$ mineralized of $846.8 \mu \mathrm{g} \mathrm{CO}_{2}-\mathrm{C} \mathrm{g}^{-1}$ of soil $(37 \%)$, for an accumulated of $2,273.5 \mu \mathrm{g}$ $\mathrm{CO}_{2}-\mathrm{C} \mathrm{g}^{-1}$ of soil. The highest dose $\left(\mathrm{T}_{5}\right)$ tested showed a $75 \%$ from a labile $\mathrm{C}$ and $25 \%$ from a $\mathrm{C}$ mineralized, amounting $3,165.9 \mu \mathrm{g} \mathrm{CO}_{2}-\mathrm{C} \mathrm{g}^{-1}$ of soil, which was $39 \%$ higher than the accumulated $\mathrm{CO}_{2}-\mathrm{C}$ of $\mathrm{T}_{2}$. A cumulative $\mathrm{CO}_{2}-\mathrm{C}$ evolution along time clearly showed two stages representing the decomposition of the active and less readily decomposable organic carbon, respectively. This response was also reported by Saviozzi et al. (1993) when studying the decomposition of vegetation-water sludge in soil. Also, a similar kinetic trend was found by Marstorp and Kirchmann (1991) on determining $\mathrm{CO}_{2}-\mathrm{C}$ from decomposing plant material in a pot experiment.

Previous data showed microorganisms needed more time to decompose labile $\mathrm{C}$ compounds in the salmon sludge when the dose increased. The model proposed by Jenkinson (1977) described well the decomposition kinetics of salmon sludge. The parameter values calculated can be used for comparisons of different sludges applied to soil and for predictions of the kinetics under changing environmental conditions. The results also contribute to the development of kinetic models to describe decomposition and oxidation of sludges over a wide range of temperatures (Shanableh and Imteaz, 2008). Finally, this information seems to be very useful for making decisions on applying salmon sludge in Alfisols, and therefore is necessary to take more precautions when using salmon sludge as amendments to soil at rate higher than $100 \mathrm{t} \mathrm{ha}^{-1}$.

\section{CONCLUSIONS}

Salmon sludge addition stimulated soil microbial population in the degraded Alfisol for an incubation period of 60 days. Higher microbial activity was directly correlated with increased dose of salmon sludge, showing a notorious impact on biological activity when land-farmed sludge was amended to soil at 100 and $150 \mathrm{t} \mathrm{ha}^{-1}$. Amendments represented a new $\mathrm{C}$ source to the Alfisol, so stimulating microbial activity.

The two-component first-order model showed a good correlation with data of the $\mathrm{CO}_{2}-\mathrm{C}$ evolution along time. In this experiment $\mathrm{C}$ mineralization dynamics showed the presence of a source of a labile $\mathrm{C}$ and a pool of a mineralized $C$. The first term of the equation $\left(C_{1} \cdot\left(1-e^{-k_{1} \cdot t}\right)\right)$ represented the pool of a labile $C$, whereas the second term $\left(C_{2} \cdot\left(1-e^{-k_{12} \cdot t}\right)\right)$ refers to a pool of a mineralized $C$. At the end of the incubation period, land-farmed sludge amended to $25 \quad \mathrm{t} \mathrm{ha}^{-1}$ accumulated $44 \%$ of $\mathrm{CO}_{2}-\mathrm{C}$ from a labile $\mathrm{C}$ source and $56 \%$ from a mineralized $\mathrm{C}$ pool, whereas at 150 $\mathrm{t} \mathrm{ha}^{-1}$ showed a $76 \%$ of a labile $\mathrm{C}$ and 24\% mineralized C.

The model showed that microorganisms needed more time to decompose labile $\mathrm{C}$ compounds in the salmon sludge when dose increased, so more care is needed when amending at high rates. The resulting kinetic model adequately represented OM decomposition of salmon sludge, in terms of $\mathrm{CO}_{2}-\mathrm{C}$ produced by soil microorganisms during respiration. 


\section{ACKNOWLEDGEMENTS}

The authors wish to thank financial support granted by the Dirección de Investigación de la Universidad de Concepción, through Project DIUC 208.153.018-1.0. Also to Mr. Alejandro Pino N., veterinary doctor, for his helpful assistance on obtaining the salmon sludge samples.

\section{REFERENCES}

Alef, K. 1995. Soil respiration. In: K. Alef, P. Nannipieri (ed). Methods in applied soil microbiology and biochemistry. Academic Press Limited, San Diego, USA, pp. 214-218.

Anderson, J.P. 1982. Soil respiration. In: A.L. Page, R.H. Miller, D.R. Keeney (ed). Methods of soil analysis: Chemical and Microbiological properties. $2^{\mathrm{a}}$ ed. American Society of Agronomy Inc, Wisconsin, USA, pp. 831-871.

Alvear, M., Urra, C., Huaiquilao, R., Astorga, M., Reyes, F. 2007. Actividades biológicas y estabilidad de agregados en un suelo del bosque templado chileno bajo dos etapas sucesionales y cambios estacionales. J. Soil Sc. Plant Nutr. 7, $38-50$.

Barrena, R., Vázquez, F., Sánchez, A. 2006 The use of respiration indices in the composting process: a review. Waste Manage. Res. 24, 3747.

Bernal, M.P., Sánchez-Monedero, M.A., Paredes, C., Roig, A. 1998. Carbon mineralization from organic wastes at different composting stages during their incubation with soil. Agr. Ecosyst. Environ. 69, 175-189.

Celis, J., Sandoval, M., Zagal, E. 2009. Actividad respiratoria de microorganismos en un suelo patagónico enmendado con lodos salmonícolas. Arch. Med. Vet. 41, 277-281.

Celis, J., Sandoval, M., Zagal, E., Briones, M. 2007. Bioensayos de fitotoxicidad de residuos orgánicos en lechuga y ballica anual realizados en un suelo Alfisol degradado. R.C. Suelo Nutr. Veg. 7, 51-60.
Cheshire, M., R. Inkson, C. Mundie, G. Sparling. 1988. Studies on the rate of decomposition of plant residues in soil floowing the changes in sugar componentes. J. Soil Sci. 39, 227-236.

Crecchio, C., Gelsomino, A., Ambrosoli, R., Minati, J., Ruggiero, P. 2004. Functional and molecular responses of soil microbial communities under differing soil management practices. Soil Biol. Biochem. 36, 1873-1883.

Esparza, J., Diez, M., Gallardo, F. 2004. Aplicación de lodos de la industria de celulosa a suelos Andisoles chilenos. En: M. Mora (ed). Simposio Residuos Orgánicos y su Uso en Sistemas Agroforestales. Universidad de la Frontera, Temuco, Chile, pp. 27-38.

Guerrero, C., Moral, R., Gómez, I., Zornoza, R., Arcenegui, V. 2007. Microbial biomass and activity of an agricultural soil amended with the solid phase of pig slurries. Bioresour. Technol. 98, 3259-3264.

Ianotti, D., Pang, T., Toth, B. 1994. A quantitative respirometric method for monitoring compost stability. Compost Sci. Utiliz. 1, 52-65.

Janssen, B.H. 1984. A simple method for calculating decomposition and accumulation of young soil organic matter. Plant Soil 76, 297-304.

Jenkinson, D.S. 1977. Studies on the decomposition of plant material in soil. J. Soil Sci. 28, 424-434.

Jonsen, K., Jacobsen, C., Torsvik, V. 2001. Pesticide effects on bacterial diversity in agricultural soils. Biol. Fertil. Soils 33, 443-453.

Marstorp, H., Kirchmann, H. 1991. Carbon and nitrogen mineralization and crop intake of nitrogen from six green manure legume decomposing in soil. Acta Agri. Scand. 41: 243252.

Millaleo, R., Montecinos, C, Rubio, R., Contreras, A., Borie, F. 2006. Efecto de la adición de compost sobre propágulos micorrícicos arbusculares en un suelo volcánico del centro sur de Chile. R.C. Suelo Nutr. Veg. 6 , 26-39.

Muñoz, C., Sierra, V., Zagal, E. 2004. Efecto de la degradación del suelo sobre la actividad microbiana en un suelo granítico del secano interior de la VII región. En: M. Mora (ed). Simposio Residuos Orgánicos y su Uso en 
Sistemas Agroforestales. Universidad de la Frontera, Temuco, Chile, pp. 287-294.

Pérez, C., González, J. 2001. Diagnóstico sobre el estado de degradación del recurso suelo en el país. Instituto de Investigaciones Agropecuarias, CRI Quilamapu, Chillán. 196 p.

Pinochet, D., Artacho, P., Azúa, P. 2001 Potencialidad como abono orgánico de los desechos sólidos subproductos del cultivo de especies salmonídeas. Agro Sur 29, 78-82.

Ros, M., Hernández, M., García, C. 2003. Soil microbial activity after restoration of a semiarid soil by organic amendments. Soil Biol. Biochem. $35,463-469$.

Ros, M., Pascual, J., García, C., Hernández, M., Insam, M. 2006. Hydrolases activities, microbial biomass and bacterial community in a soil after long-term amendment with different compost. Soil Biol. Biochem. 38, 3443-3452.

Santibáñez, F., García, A. 2000. Suelos. En Informe País, Estado del Medio Ambiente en Chile. Universidad de Chile, LOM Ediciones, Santiago, pp. 203-244.

Saviozzi, A., R. Riffaldi, R. Levi-Minzi, A Scagnozzi, G. Vanni. 1993. Decomposition of vegetation-water sludge in soil. Bioresour. Technol. 44, 223-228.

Sawyer, C., Mccarty, P., Parkin, G. 2003. Chemistry for Environmental Engineering and Science. McGraw- Hill Inc, New York, NY, 752 p.
Shanableh, A., M. Imteaz. 2008. First-order hydrothermal oxidation kinetics of digested sludge compared with raw sludge. Environ. Technol. 29, 1009-1020.

Stolpe, N., Zagal, E., Sandoval, M., Quezada, C. 2008. Southern Field-Guide. In: M. Casanova, W. Luzio (ed). The International Conference \& Field Workshops on Soil Classification. Departamento de Suelos y Recursos Naturales, Facultad de Agronomía, Universidad de Concepción, Chile. 94 p.

Sylvia, D., Fuhrmann, J., Hartel, P., Zuberer, D. 1998. Principles and Applications of Soil Microbiology. Prentice Hall, Upper Saddle River, NJ, $550 \mathrm{p}$.

Teuber, N., Salazar, F., Alfaro, M. Valdebenito, A. 2007. Efecto de diferentes dosis de lodos de la crianza de salmones en el cultivo de papa y su efecto residual en ballica anual. Agric. Téc. (Chile) 67, 393-400.

Varnero, M.T., Faúndez, P., Santibáñez, C., Alvarado, P. 2004. Evaluación de lodo fresco y compostado como materia prima para la elaboración de sustratos. En: M. Mora (ed). Simposio Residuos Orgánicos y su Uso en Sistemas Agroforestales. Universidad de la Frontera, Temuco, Chile, pp. 477-481.

Zagal, E., Rodríguez, N., Vidal, I., Quezada, L. 2002. Actividad microbiana en un suelo de origen volcánico bajo distinto manejo agronómico. Agric. Téc. (Chile) 62, 297-309. 